\title{
Metabolic changes in some acclimation phenomena
}

\author{
KARI LAGERSPETZ \\ Department of Zoology, University of Turkti, Turku, Finland
}

\begin{abstract}
KURZFASSUNG: Stoffwechselveränderungen bei einigen Akklimatisierungsphänomenen. Schon in früheren Untersuchungen wurde nachgewiesen, daß die Akklimatisierung von Ratten an konstante niedrige Temperaturen von stoffwechselphysiologischen Veränderungen im Bereich der Zellen begleitet werden. Nach unseren Untersuchungen verursacht Anpassung an konstante niedrige Temperaturen auch bei Laboratoriumsmäusen eine Abnahme der Intensität des Muskelzitterns in der Kälte, einen Anstieg der Stoffwechselrate des Tieres sowie der Aktivität des Sukzinodehydrogenase-Komplexes in Leber und Skelettmuskeln. Die Sukzinodehydrogenaseaktivität in der Leber männlicher Mäuse zeigt eine Abhängigkeit von der Anpassungstemperatur, zumindest über den Bereich von $5^{\circ}$ bis $32^{\circ} \mathrm{C}$. Mäuse können ferner daran angepaßs werden, daß sie wirksamer auf kurzfristige Kälteeinwirkungen reagieren. Derartige Anpassungen beeinflussen jedoch nicht die Stoffwechselrate oder die Aktivität des Sukzinodehydrogenase-Komplexes in der Leber, sondern verursachen eine gesteigerte stoff wechselphysiologische Reaktion auf injiziertes 1-Noradrenalin. Die induzierte Widerstandsfähigkeit gegenüber der temperatursenkenden Wirkung des Phenothiazinderivates Promazin entfaltet sich bei Mäusen in einer thermoneutralen Umgebung langsamer als bei Zimmertemperatur. Dieser Umstand deutet auf Ahnlichkeiten hin, welche bei den ersten Stadien der Promazintoleranz und der Akklimatisierung an kurzfristige Kälteeinwirkungen bestehen.
\end{abstract}

\section{INTRODUCTION}

Acclimation phenomena occur as relatively slow regulatory responses to several different types of external variations. The animals can thus compensate for changes in ambient temperature, oxygen content, osmotic pressure, etc. Repeated administration of chemical compounds, just as some drugs and insecticides may also induce a tolerance to their effects in animals. As examples of acclimation phenomena which are accompanied by metabolic changes, two topics will be considered in this paper: (1) the temperature acclimation in homoiotherms, especially in small mammals, and (2) the development of induced tolerance to the drug promazine in these animals.

As Professor PRECHT and his school in Kiel have shown, temperature acclimation of metabolic functions in poikilotherms results in relative constancy of metabolic rates in spite of variations in ambient temperature. In homoiotherms, relative constancy of metabolic rates is caused by regulation of body temperature. In these animals, variations in external temperature affect the functional state of the thermoregulatory system. The relative significance of these different components in the maintenance of a constant body temperature changes in turn during prolonged stay at a given constant external temperature. Thus already the classical studies of GeLrneo $(1934,1949)$ 
revealed the large increase in heat production of mammals and birds during experimental acclimation to constant cold. HART, Héroux and Depocas in Canada have extensively studied the nature of thermogenesis in cold-acclimated rats. In a cold environment muscle shivering is the most important method of thermogenesis in animals acclimated to a temperature of about $30^{\circ} \mathrm{C}$. However, during prolonged stay in cold, muscle shivering is replaced by a so-called non-shivering thermogenesis, which occurs in visceral, but mostly in non-visceral tissues, probably in the skeletal muscle (Depocas 1958, 1960) and also in the brown adipose tissue, as has been reported by Dr. SMrTH during this symposium. Cold acclimation in the rat involves an increase in the calorigenic effect of noradrenaline (HSIEH \& Carlson 1957, Depocas 1960). Hence, noradrenaline is at present considered the most probable mediator of the metabolic effects of cold acclimation.

Several changes in cell metabolism have been observed to occur during cold acclimation (SMITH \& Horjer 1962). YOU \& Sellers already in 1951 demonstrated the increase of oxygen consumption of various tissues during cold acclimation. In a series of studies, HanNon \& VAughan $(1960 a$, b) and Hannon $(1959,1960)$ have shown that the activities of several enzymes in the liver and in the skeletal muscle in rats change during cold acclimation. Especially obvious is the increase of the succinic dehydrogenase activity in the liver (for review see Depocas 1961 and Smith \& HoIJER 1962). The $\mathrm{P} / \mathrm{O}$ ratio in liver mitochondria seems also to be lowered (SMITH \& Fatrhurst 1958, Panagos et al. 1958), thus indicating a decrease in the efficiency of the oxidative phosphorylation and an increased escape of chemical energy as heat.

In our laboratory, some studies on the cold acclimation are in progress. Albino laboratory mice have been used as experimental animals. In a cold environment $\left(8^{\circ}\right.$ to $10^{\circ} \mathrm{C}$ ) the animals which were previously acclimated to $5^{\circ} \mathrm{C}$ for 4 to 14 days showed less muscle shivering than mice kept at $24^{\circ} \mathrm{C}$, and the latter less than animals kept at $32^{\circ} \mathrm{C}$ (LAgerspetz 1963b). Oxygen consumption of the cold-acclimated animals was almost doubled (authors unpublished observations). The activity of the succinic dehydrogenase complex in liver homogenates was measured using the method of KuN \& Aвоор (1949). Enzyme activity in mice acclimated to $5^{\circ} \mathrm{C}$ for a week was significantly higher than that in mice kept at $24^{\circ} \mathrm{C}$ (LAGERSPETz et al. 1962). Thus earlier observations on rats were confirmed by us, using mice as test animals.

\section{RESULT'S AND DISCUSSION}

Mr. Harri TARKKonen of our laboratory has continued the study of metabolic changes occurring during cold acclimation in mice. When mice are transferred to an ambient temperature of $5^{\circ} \mathrm{C}$, the activity of the succinic dehydrogenase complex in liver is not altered in 12 hours but increases significantly within 24 hours and keeps on this higher level for two weeks, after which a decline of the activity occurs even in the cold. If mice are acclimated to $32^{\circ} \mathrm{C}$, enzyme activity decreases within one day, but returns again to the original level after about two weeks. The changes observed are thus opposite to those found after the transfer of the animals to constant cold. 
An attempt to acclimate mice to various constant environmental temperatures for one week was also made. The activity of the succinic dehydrogenase complex in the liver homogenates was determined. As can be seen from Figure 1, enzyme activity in these conditions was found to be dependent on the acclimation temperature.

The total energy production of the liver is relatively small when compared with the large mass of skeletal muscle. Since skeletal muscles seem to be especially important also in the non-shivering thermogenesis, studies on changes in the enzyme pattern in

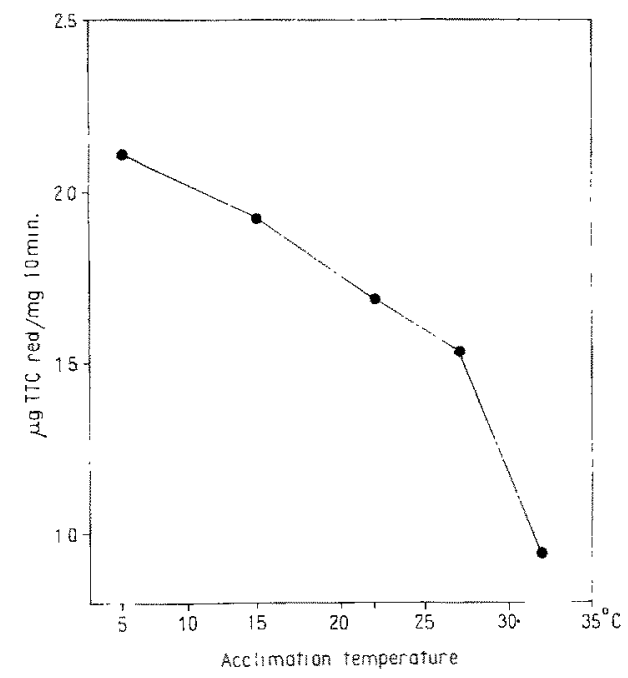

Fig. 1: Activity of the succinic dehydrogenase complex in liver homogenates of male mice as a function of acclimation temperature. Acclimation interval: 7-8 days; 7 animals in each group

muscle would be very interesting. The only observation we have hitherto made is that the activity of the succinic dehydrogenase complex also increases during cold acclimation in muscle homogenates from mice (TARKKONEN unpublished). In several papers, HART, HÉroux and DEPOCAs have pointed out that there are important physiological differences between rats acclimated to constant cold in the laboratory and those acclimated to outdoor winter conditions. In contrast to the experiments described above, some observations were also made concerning a third type of acclimation to cold, the acclimation to short cold exposures.

The experiments performed by Mr. TrRRI consisted in exposing mice individually for two hours each day to a temperature of about $0^{\circ} \mathrm{C}$ in small containers. The colonic temperature of the animals was measured with a thermocouple immediately before the experiment and at intervals of 30 minutes in the cold. Under these conditions the colonic temperature fell during the first day some $5^{\circ} \mathrm{C}$; however, within a few days the animals were able to keep their body temperature higher during cold exposure. This is shown in Figure 2. The short cold exposure acclimation thus differed in some respects from acclimation to constant cold. There were no differences in oxygen consumption of the short exposure cold-acclimated and control groups at $24^{\circ} \mathrm{C}$. Neither were there 
any differences in the activity of the succinic dehydrogenase complex in liver homogenates.

The metabolic response to a single injection of 1-noradrenaline was also studied using animals acclimated to short cold exposures. This was done by narcotising the animals slightly through intraperitoneal injections with sodium pentobarbital $(45 \mathrm{mg} /$ $\mathrm{kg}$ ) and by measuring their oxygen consumption using an open circuit Pauling para-

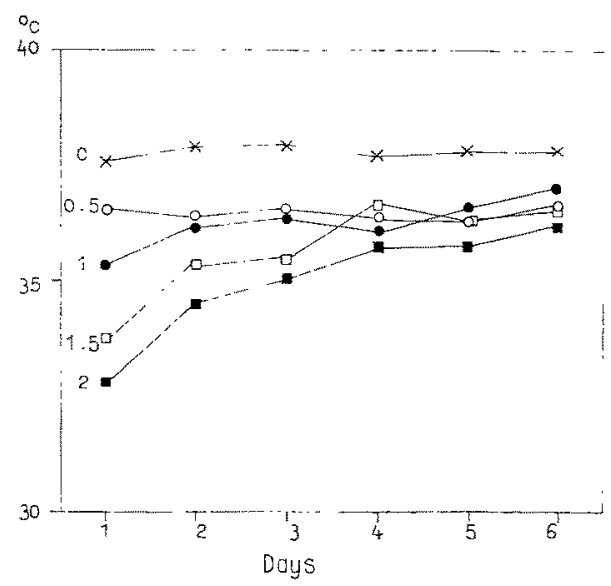

Fig. 2: Acclimation of male mice to daily short-term exposures to cold. Graph C: mean colonic temperature before cold exposure. Time in hours from the beginning of cold exposure is indicated left of each graph; 8 test animals

\section{Table 1}

The effect of $1 \mathrm{mg}$ per $\mathrm{kg}$ l-noradrenaline (NA) on the oxygen consumption $(\mathrm{ml} / \mathrm{g} \cdot \mathrm{h})$ of male mice acclimated to daily short cold exposures during eight days. Pentobarbital narcosis (45 mg per kg I. P.)

\begin{tabular}{|lcccr|}
\hline & Before NA injection & \multicolumn{3}{c|}{ After NA injection } \\
\hline Time in minutes & $0-15$ & $0-10$ & $10-20$ & $20-30$ \\
Controls $(8)$ & 1.35 & 2.23 & 2.27 & 2.03 \\
Acclimated $(8)$ & 1.40 & 2.77 & 3.10 & 2.71 \\
\hline
\end{tabular}

magnetic oxygen analyzer system. During narcosis, $1 \mathrm{mg} / \mathrm{kg} 1$-noradrenaline was injected intraperitoneally and oxygen consumption again measured for 30 minutes at $24^{\circ} \mathrm{C}$. The results are shown in Table 1 . It appears that the animals acclimated to short cold exposures are more responsive to noradrenaline than the controls, the difference in the oxygen consumption values being statistically significant $(p<0.01)$. The increased sensitivity to noradrenaline is a feature also common to both white rats acclimated to constant cold (DEPOCAS 1960) and to wild Norway rats captured during winter (HÉroux 1962). Hence increased metabolic responsiveness to noradrenaline seems to be a common denominator for the different types of cold acclimation and seasonal winter acclimatization which have been studied.

Promazine is a phenothiazine drug, well known for its tranquilizing effects in 
humans. Courvorsier et al. (1953) in their pioneer study on the pharmacology of phenothiazines observed the prominent hypothermisant effect of these drugs in small mammals. Already in rather small doses $(5 \mathrm{mg} / \mathrm{kg}$ ) promazine causes a drop in body temperature of mice (LAgerspetz \& TIRri 1958). The decrease in body temperature

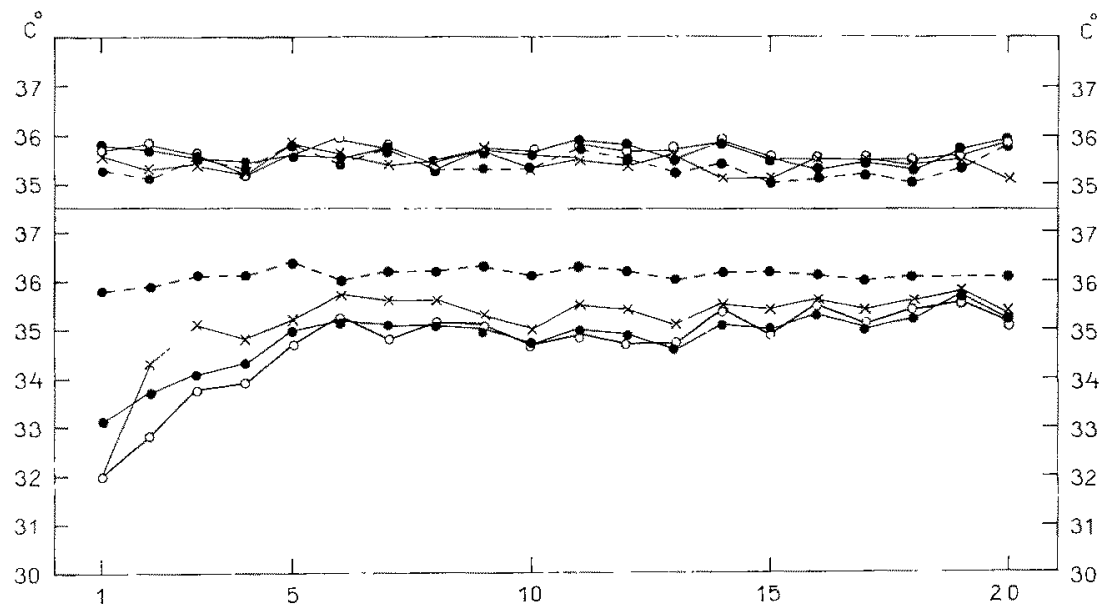

Fig. 3: Development of induced tolerance to promazine. Mean colonic temperatures of mice before injection (black dots with interrupted line), and respectively 0.5 (black dots), 1 (open circles) and 3 hours (crosses) after injection of Ringer's solution (upper part of Fig.) or of $10 \mathrm{mg}$ promazine per $\mathrm{kg}$ (lower part of Fig.). Horizontal: time in days after beginning of daily administration; 20 animals in both groups

Table 2

Differences between the colonic temperatures measured before and one hour after the injection of Ringer's solution (controls) or $10 \mathrm{mg}$ promazine per $\mathrm{kg}$ (experimental). The values of thave been calculated according to the method for dependent measures

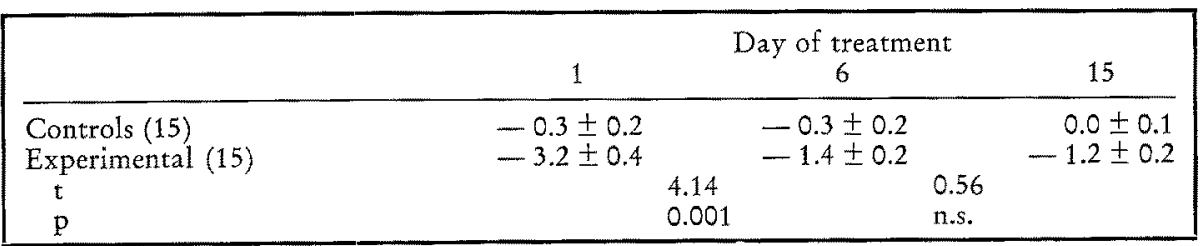

is of course dependent on the external temperature (LAgerspetz \& TirRi 1958, LAGERSPETZ 1963b). We observed that daily administrations of promazine induce a tolerance to its effect on body temperature (LAgerspetz \& TIRri 1961, LAgersPeTZ 1963a). If the colonic temperature of the animals is measured daily before injection, and again say one hour after it, the decrease in body temperature caused by promazine diminishes in about 5 to 6 days (LAGERSPETz 1963a). This result is shown in Figure 3 and in Table 2.

Later experiments by Mr. TIRRI have shown that if the decrease of body temperature is prevented by keeping the animals in a thermoneutral environment (about $33^{\circ} \mathrm{C}$ ), tolerance to promazine develops much more slowly, namely in about 7 to 8 weeks. This 
seems to indicate that the tolerance to the hypothermisant effect of promazine would be, at least for the most part, only a cold acclimation phenomenon, similar to that which occurs in response to short cold exposures during which the body temperature also decreases.

However, animals which had received promazine daily for one week at $24^{\circ} \mathrm{C}$ and thus were tolerant to its hypothermisant effects were not able to keep their body temperature higher than the controls when animals of both groups were subjected to an ambient temperature of about $2^{\circ} \mathrm{C}$ individually in small containers. Hence we feel that the induced tolerance to promazine is not merely comparable to acclimation to short cold exposures but is a more specific phenomenon. Several enzymes have been shown earlier to be inhibited by promazine. Our attempts to correlate promazine tolerance with changes in the activities of some of these enzymes in brain homogenates were unsuccessful (LAgERsPetz \& TrRRI 1963). No significant differences were found in the succinic dehydrogenase complex activity, in the cytochrome $c$ oxidase activity or in the FAD concentration in brain homogenates from tolerant and control mice. At present the work on promazine tolerance in mice is directed to the excretion of promazine and to the effects of catecholamines in tolerant and control animals.

In conclusion, the scattered observations presented above are more of a working program than a ready basis for interpretations. However, they seem to point out the special importance of two approaches in the study of the physiological variations of metabolism. First, attempts are needed to correlate biochemical data of tissue metabolism with the physiology of cell organelles, e. g., the mitochondria. Secondly, the importance of the nervous system and the neurohumours, especially of the catecholamines as mediators of acclimative metabolic responses in vertebrates, should be stressed.

\section{SUMMARY}

1. Acclimation to constant cold also causes in mice a decrease in the intensity of muscle shivering in cold and an increase in the metabolic rate of the animal and in the succinic dehydrogenase complex activity in the liver and skeletal muscles.

2. The succinic dehydrogenase complex activity in the liver depends on the acclimation temperature at least over a range from $5^{\circ}$ to $32^{\circ} \mathrm{C}$.

3. Acclimation of mice to short-term exposures to cold does not affect metabolic rate of the animals or the succinic dehydrogenase complex activity in the liver but causes an increase in the metabolic response to injected l-noradrenaline.

4. The induced tolerance to the hypothermisant effect of promazine in mice develops slower in a thermoneutral environment than at room temperature.

\section{LITERATURE CITED}

Courvolsier, S., Fournel, J, Ducrot, R, Kolsky, M. \& Koetschet, P., 1953. Propriétés pharmacodynamiques du chlorhydrate de chlor-3(dimethylamino-3 propyl)-10 phénothiazine, Arch. int. Pharmacodyn. 92, 305-361.

Depocas, F., 1958. Chemical thermogenesis in the functionally eviscerated cold-acclimated rat. Canad. J. Biochem. Physiol. 36, 691-699. 
- 1960. The calorigenic response of cold-acclimated white rats to infused noradrenaline. Canad. J. Biochem. Physiol. 38, 107-114.

- 1961. Biochemical changes in exposure and acclimation to cold environments. Brit. med. Bull. 17, 25-31.

Gelineo, S., 1934. Influence du milieu thermique d'adaptation sur la thermogenèse des homéothermes. Ann. physiol. physicochém. biol. 10, 1083-1115.

- 1955. Température d'adaptation et production de chaleur chez les oiseaux de petite taille. Arch. Sci. physiol. 9, 225-243.

HANNON, J. P., 1959. Effect of prolonged cold exposure on oxidative phosphorylation and adenosinetriphosphatase activity of rat liver tissue. Am. J. Physiol. 196, 890-892.

- 1960a. Effect of prolonged cold exposure on components of the electron transport system. Am. J. Physiol. 198, 740-744.

- 1960b. Tissue energy metabolism in the cold-acclimatized rat. Fed. Proc., Pat. II, 19, 139-144.

- \& Vaughan, D. A., 1961. Effect of exposure duration on selected enzyme indexes of cold acclimation. Am. J. Physiol. 200, 94-98.

Héroux, O., 1962. Seasonal adjustments in captured wild Norway rats. II. Survival time, pelt insulation, shivering, and metabolic and pressor responses to noradrenaline. Canad. J. Biochem. Physiol. 40, 537-545.

Hsteh, A. C. L. \& Cartson, L. D., 1957. Role of adrenaline and noradrenaline in chemical regulation of heat production. Am. J. Physiol. 190, 243-246.

Kun, E. \& Aвood, L. G., 1949. Colorimetric estimation of succinic dehydrogenase by triphenyltetrazolium chloride. Science 109, 144-146.

LAGERSPETZ, K., 1963a. The induction of physiological tolerance to promazine in mice. II. The development of induced tolerance. Ann. med. exp. Fenn. 41, 214-219.

- 1963b. Temperature acclimation and experimental temporary poikilothermia in mice. Ann. med. exp. Fenn. 41, 202-213.

- Tarkmonen, H. \& Tirri, R., 1962. Effect of cold acclimatization on the succinic dehydrogenase activity in the liver and brain tissues of mice. Experientia 18, 552 .

- \& Tirri, R., 1958. The production of temporary poikilothermia in mice by promazine hydrochloride and the effect of insulin on the body temperature of mice. Arch. Soc. zool.bot. fenn. Vanamo 12, 185-194.

-, - 1961. The induction of physiological tolerance to promazine in mice. Ann. med. exp. Fern. 39 (suppl. 5), 1-24.

,--1963 . The induction of physiological tolerance to promazine in mice. III. Respiratory enzymes in the brain in induced tolerance. Ann. med. exp. Fenn. 41, 315-318.

Panagos, S., Beyer, R. E. \& Masoro, E. J., 1958. Oxidative phosphorylation in liver mitochondria prepared from cold-adapted rats. Biochem. biophys. Acta 29, 204-205.

Smith, R. E. \& FAIRHURst, A. S., 1958. A mechanism of cellular thermogenesis in cold-adaptation. Proc. nat. Acad. Sci., Wash. 44, 705-711.

- \& Horjer, D. J., 1962. Metabolism and cellular function in cold acclimation. Physiol. Rev. $42,60-142$.

You, R. W. \& SELLERS, E. A., 1951. Increased oxygen consumption, and succinoxidase activity of liver tissue after exposure of rats to cold. Endocrinology 49, 374-378.

\section{Discussion following the paper by LAGERSPETZ}

GraINGER: A student of mine, Miss Cecily Joyce, has found that by warming one ear and cooling the other ear of the same rabbit, the succinic dehydrogenase activity of the isolated skin from these ears reaches the same levels as are found in warm and cold adapted rabbits respectively, thus showing that in some mammalian tissues, environmental temperature has a direct effect in bringing about adaptive changes in enzymes.

LAGERSPETZ: This is yery interesting evidence for a direct temperature influence on the activity of succinic dehydrogenase in animals exposed to cold. 